\title{
遠赤外線ヒータの分光放射特性の簡易評価方法*
}

小笠原永久 ${ }^{* 1}$ ，木村嘉孝 ${ }^{* 2}$

\section{Simple Method for Spectral Evaluation of Radiation Energy from Far Infrared Heater}

\author{
Nagahisa OGASAWARA ${ }^{* 1}$ and Yoshitaka KIMURA \\ ${ }^{* 1}$ National Defense Academy, Dept. of Mechanical Engineering \\ 1-10-20 Hashirimizu, Yokosuka, 239-8686 Japan
}

\begin{abstract}
An useful method for a spectral evaluation of a radiation energy was developed for far infrared heaters. The system consists on a simple radiometer and two band-pass filters; vitreous Silica and Silicon, which have different transmission. Numerical simulations with Microsoft Excel made sure this method works well. The experimental data obtained by this method gave the fact that a far infrared type heater radiates enough energy in a far infrared region even at high temperature as much as a black body does. It means a far infrared type heater can work effectively enough at high temperature for industry heating. This method can classify a type of a heater with the ratio of a near infrared energy and a far infrared energy in practical use. By using this data, the authors also proposed a simple identification method of spectral emissivity of far infrared heater made of ceramics. This inverse method could determine approximated values for real heaters.
\end{abstract}

Key Words : Thermal Radiation, Spectroscopic Measurement, Ceramics, Inverse Problem, Far Infrared, Radiometer

\section{1. 緒言}

遠赤外線ヒータは，食品・塗料・樹脂・電子部品等幅広い材料に対し，加熱・乾燥・反応促進・燒成ほか様々 な目的で活用されている，効率の良い放射加熱を行うためには，対象物の吸収特性だけでなく，加熱製品の分光 放射特性を把握する必要がある. 食材, 建材, セラミックス（陶磁器）などの産業界における被加熱材料の多く は，一般的に遠赤外域での放射率が高く，加熱製品の遠赤外域放射効率が特に重要となる(1). 素材材料の分光放 射率は，フーリエ変換赤外分光光度計（FTIR）を用いて測定できるが(2)，遠赤外線ヒータなど加熱製品の分光放 射率については，ヒータ形状や内部電熱線による加熱状況，赤外線放射面の向き，隣接ヒータや他熱源からの放 射などの稼働環境を維持したまま，直接に測ることは難しく，手間と時間を要するという問題がある.

一方で，欧米を中心とする海外の産業界では，遠赤外線ヒータは高温での放射効率が下がるため高温使用を避 けるべきとの解釈をされることがある(3). これは，遠赤外線ヒータの放射エネルギーを波長帯域別に計測かつ比 較した報告例が少ないこともあり，ウィーンの変位則を過剰に考慮したことによる誤解と思われる.

そこで本研究では, FTIR 装置などより安価な放射計を用いて遠赤外線ヒータの放射エネルギーを実測すること で，高温使用時の放射効率に関する欧米の解釈が誤りであることを実証し，遠赤外線ヒータの放射特性の意義を 明らかにすると共に，被加熱材料との適合性をも推察できるようにすることを目的とする．具体的には，複数の バンドパスフィルターを装着した 1 台の放射計を用いて波長帯域別の放射エネルギーを測定し, 遠赤外線ヒータ の分光放射特性を評価する方法を開発した.

なお，赤外線の帯域区分には，近赤外域と遠赤外域の区分の他に，中赤外域を区分するか否かも含めて諸説が

* 原稿受付 2010 年 4 月 26 日

*1 正員, 防衛大学校（广239-8686 神奈川県横須賀市走水 1-10-20）

*2 木村技術事務所

E-mail: oga@nda.ac.jp 
ある(4)(5). 本研究においては，実際の遠赤外線ヒータの放射領域，実験で使用するフィルターの透過特性および放

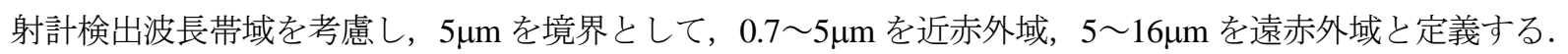

\section{2. 遠赤外線ヒータ}

遠赤外線ヒータ（以下，ヒータ）は，高温に熱した放射面から赤外線を放射し，対象材料を放射加熱する装置 である．その放射面には，焼結成形されたセラミックスの板や，金属製の管や板にセラミックスを溶射したもの などがあり，一般的に，分光放射特性によって遠赤外型・黒体型の 2 種類に大別される(6). 遠赤外型ヒー夕は， 近赤外波長域で低い放射率を，遠赤外波長域で高い放射率を示し，黒体型ヒータは全赤外波長域でほぼ一様の放 射率を有する. 代表的な 2 種類のヒータについて, FTIRによって測定された分光放射率 $\varepsilon(\lambda)$ の例を図 1 に示す。

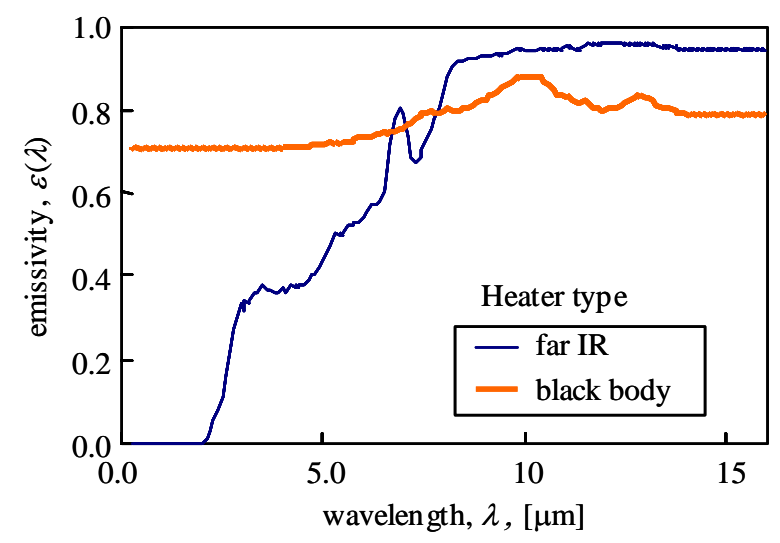

Fig. 1 Spectral emissivity of two typical IR heaters

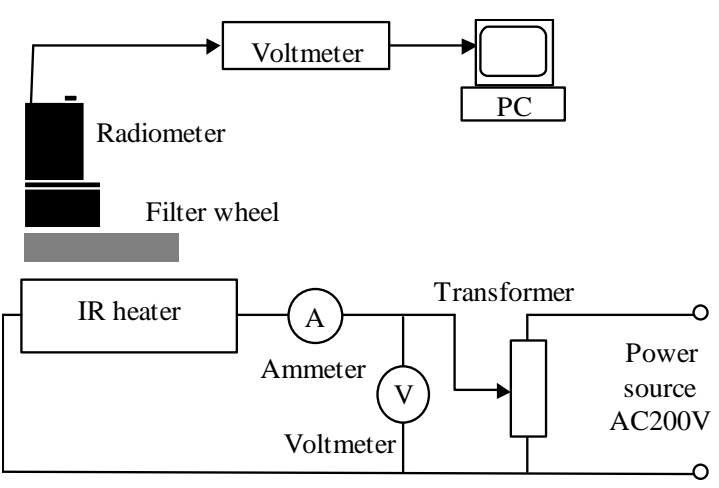

Table 1 Specification of radiometer

\begin{tabular}{|c|c|}
\hline Wave bands & $0.2-16[\mu \mathrm{m}]$ \\
\hline Temperature range & $273-873[\mathrm{~K}]$ \\
\hline Response time & $0.7[\mathrm{~s}]$ \\
\hline Accuracy & $\pm 1 \%$ \\
\hline Output & $0-5[\mathrm{~V}]$ \\
\hline Detection device & Thermopile \\
\hline Optical system & Cassegrain \\
\hline
\end{tabular}

Fig. 2 Schematic diagram for experiment

\section{3. 波長帯域別放射エネルギ一測定実験}

\section{$3 \cdot 1$ 実験装置}

図 2 に実験装置概略を示す. 本装置は, ヒータへの供給電力を計測および調整する電流計, 電圧計, 変圧器と, ヒータの放射エネルギーを計測・記録する放射計，バンドパスフィルター，電圧計，パソコンから成る.

\section{$3 \cdot 2$ 放射計とバンドパスフィルター}

本研究で用いた放射計は，市販の携帯型デジタル放射温度計（チノー社製 IR-AHOT）である. 放射計の主な仕 様を表 1 に示寸．放射計は測定波長帯域の総放射エネルギー量を出力する装置であり，1 台の放射計だけの測定 データを基に，ヒータの分光放射特性を効果的に抽出することは難しい(6)(7). そこで，測定波長帯域の異なる 3 台の放射計の出力比を取ることで，ヒータの分光放射特性を判別することにした．実際には 1 台の放射計に，石 
英ガラスとシリコンの 2 種類のフィルターを付け替え, フィルター無しの場合と合わせて 3 種類の放射計として いる ${ }^{(8)}$. 約 $0 \sim 4 \mu \mathrm{m}$ の波長を透過するショートパスフィルタ（石英ガラス）を装着した場合を近赤外域放射計（\#2）

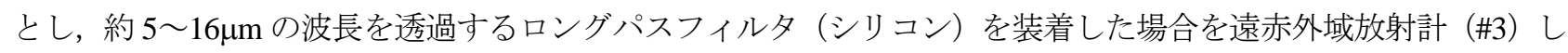
た．フィルターを装着しない場合を全域放射計（\#1）とする．フィルターを装着した場合の各放射計の分光感度 特性 $\tau_{\mathrm{i}}(\lambda)$ を図 3 および表 2 に示寸.

放射計の出力特性は, フィルター無しの状態で, 検出最大温度 873K の黒体炉を測定した時に $5 \mathrm{~V}$ となるように 設定されている. フィルターを取り付けた状態で黒体炉校正した出力特性を図 4 に示寸. フィルターはフィルタ 一ホィールに装填されており，フィルター付け替えによる放射計視野のずれが生じないように工夫している．任 意の波長 $\lambda$, 任意の温度 $T$ における黒体の単色放射能 $E_{\mathrm{b}}(T, \lambda)$ に放射計 \# $\mathrm{i}$ の分光感度 $\tau_{\mathrm{i}}(\lambda)$ を掛けると, 放射計\# $\mathrm{i}$ で測定される黒体の単色放射能 $E_{\mathrm{bi}}(T, \lambda)$ が得られる.

$$
E_{\mathrm{bi}}(T, \lambda)=E_{\mathrm{b}}(T, \lambda) \times \tau_{\mathrm{i}}(\lambda)
$$

よって, 放射計＃ｉで測定される温度 $T$ の黒体の単位面積, 単位時間当たりの放射エネルギー $E_{\mathrm{bi}}(T)$ は次式で得 られる.

$$
E_{\mathrm{bi}}(T)=\int_{\lambda_{\mathrm{si}}}^{\lambda_{\mathrm{ei}}}\left[E_{\mathrm{b}}(T, \lambda) \times \tau_{\mathrm{i}}(\lambda)\right] d \lambda
$$

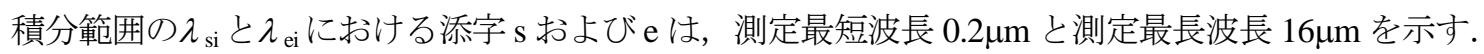

放射計出力と黒体炉温度の関係（図 4）と, 測定波長帯域の放射エネルギー量と黒体炉温度の関係（式(2) を 用いることで，放射計出力と測定波長帯域の放射エネルギー量の関係が得られる.

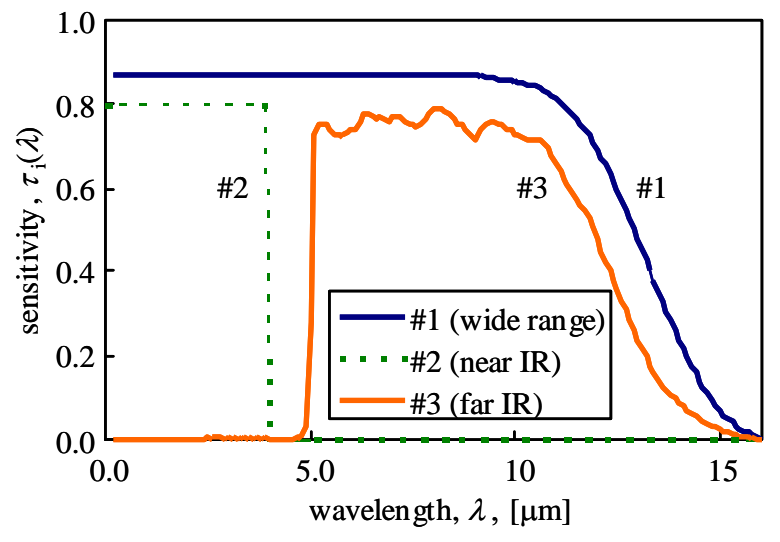

Fig. 3 Sensitivity of 3 radiometers

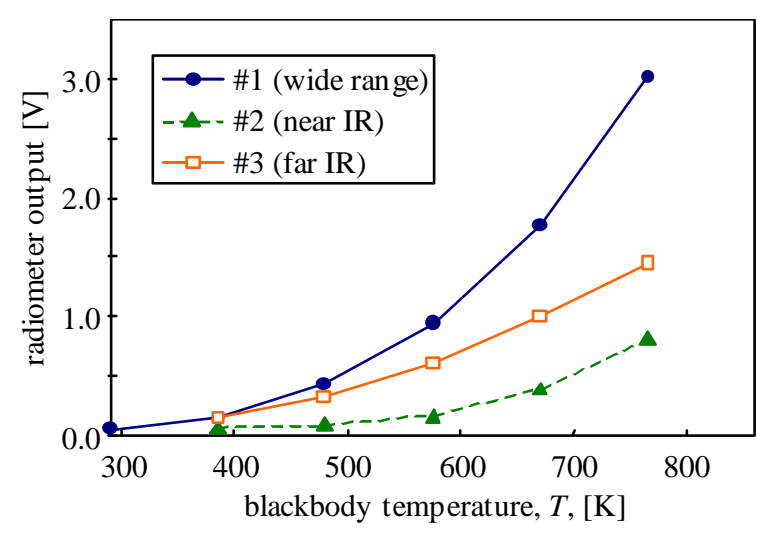

Fig. 4 Output of radiometer vs. blackbody temperature

Table 2 Detective wave bands of radiometer \#1-3

\begin{tabular}{|c|c|c|c|}
\hline number & wave bands & filter & wavelength $[\mu \mathrm{m}]$ \\
\hline$\# 1$ & wide range & open & $0.2-16$ \\
\hline$\# 2$ & near IR & Vitreous Silica & $0.2-4$ \\
\hline$\# 3$ & far IR & Silicon & $5-16$ \\
\hline
\end{tabular}

\section{$3 \cdot 3$ 実験手順}

以下に実験手順を説明する. 測定環境は常温の室内とし, 対象ヒータの表面温度を安定に保つため, 室内空気 を乱す機器を遠ざけ, 静穏な状態で測定した。 また, 放射計とヒータ間の測定距離は充分に短く, 放射エネルギ 一を減衰させる水蒸気，湿度の影響は少ないと考えた。 ヒータの放射面を水平に配置し，ヒータから見て鉛直上 方からの測定を基本とした.

(1) 対象ヒータに任意の電圧を供給する. 
(2) ヒータの表面温度が安定し定常状態になってから電圧計および電流計を確認し，入力電力を記録する.

(3) 放射計をヒータの測定点直上に設置し，ヒータ表面温度が安定するまで約 2 分間待つ. 放射計とヒータ 間の距離は $125 \mathrm{~mm}$ に固定してあり，その時の放射計視野は直径 $32.5 \mathrm{~mm}$ の円状である.

(4) フィルターホィールを回転させ, フィルターごとに 10 秒間ずつの測定を行う. 放射計の出力はパソコン に転送され，平均化処理後，測定波長帯域ごとの放射エネルギー量に変換される.

（5）測定終了後，放射計をヒータ直上から外し，同時に赤外線サーモグラフィ装置でヒータの表面温度を測 定する. 表面温度測定点には予め黒体塗料を塗布し, ヒータの放射率に依存しない正確な温度を測定で きるようにしておく.

(6) 入力電力を変え, 以上の作業を繰り返し行う.

黒体型ヒータの測定結果例を, 図 5 および図 6 上に点で示す. 図 5 はヒータ表面温度と波長帯域別放射エネル ギーの関係を, 図 6 はヒータ表面温度と 3 種類の放射エネルギーの比を表す，温度上昇とともに，遠赤外域放射 エネルギーより近赤外域放射エネルギーの増加分が多いことが分かる.なお, 線は後述の数值実験の結果である.

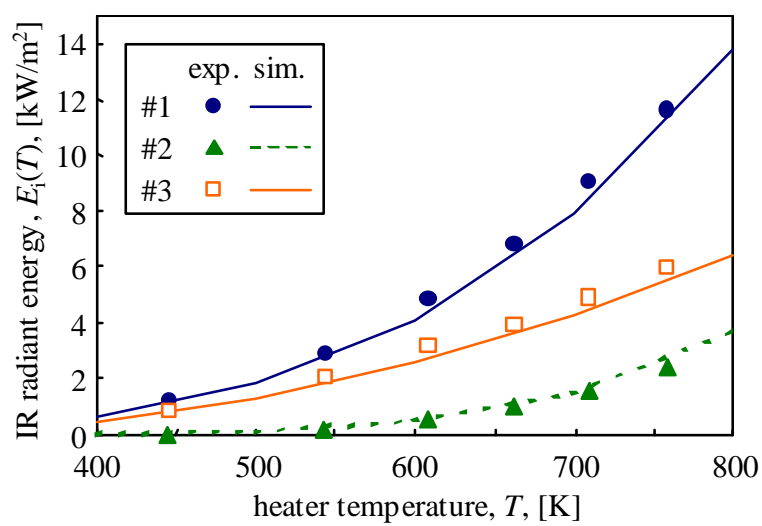

Fig. 5 IR radiant energy vs. heater temperature

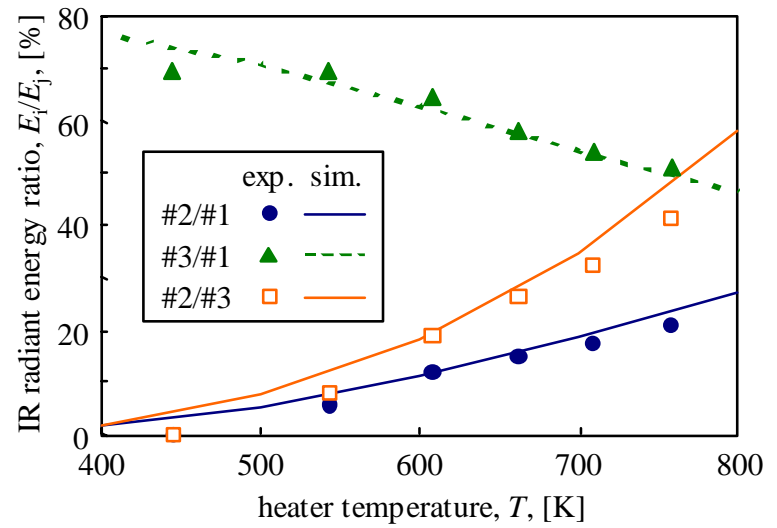

Fig. 6 IR radiant energy ratio vs. heater temperature

Table 3 Radiant error between experiment and simulation

\begin{tabular}{|c|c|c|c|c|c|c|}
\hline Temp.[K] & 446 & 543 & 609 & 662 & 709 & 758 \\
\hline \#1 (wide range) & 9.0 & 9.1 & 10 & 9.0 & 8.4 & 5.2 \\
\hline \#2 (near IR) & -100 & -21 & 10 & 3.2 & -4.2 & -6.1 \\
\hline \#3 (far IR) & 2.2 & 12 & 14 & 9.7 & 9.6 & 8.4 \\
\hline
\end{tabular}

\section{4. 数值実験}

前章で提案した実験手法の確認のため, FTIR で取得したヒータの分光放射率データと放射計の分光感度特性デ ータを利用して数值実験を行った. 使用ソフトは表計算ソフトMS-エクセルである. 任意の波長 $\lambda$, 任意の温度 $T$ における黒体の単色放射能 $E_{\mathrm{b}}(T, \lambda)$ にヒータの分光放射率 $\varepsilon(\lambda)$ を掛けると, ヒータの単色放射能 $E(T, \lambda)$ が得られる.

$$
E(T, \lambda)=E_{\mathrm{b}}(T, \lambda) \times \varepsilon(\lambda)
$$

図 7 は遠赤外型ヒータの放射スペクトル例である. ウィーンの変位則に従い，温度上昇とともに近赤外域放射 エネルギーの増加分が䡠著である. さらに, ヒータの単色放射能 $E(T, \lambda) に$, 放射計 $\# \mathrm{i}$ の分光感度 $\tau_{\mathrm{i}}(\lambda)$ を掛けると, 放射計\# $\mathrm{i}$ に入射するヒータの単色放射能 $E_{\mathrm{i}}(T, \lambda)$ が得られる.

$$
E_{\mathrm{i}}(T, \lambda)=E_{\mathrm{b}}(T, \lambda) \times \varepsilon(\lambda) \times \tau_{\mathrm{i}}(\lambda)
$$

よって, 放射計＃洸入射するヒータの単位面積, 単位時間当たりの放射エネルギー $E_{\mathrm{i}}(T)$ は次式で得られる. 


$$
E_{\mathrm{i}}(T)=\int_{\lambda_{\mathrm{si}}}^{\lambda_{\mathrm{ei}}}\left[E_{\mathrm{b}}(T, \lambda) \times \varepsilon(\lambda) \times \tau_{\mathrm{i}}(\lambda)\right] d \lambda
$$

なお今回の研究では, 分光放射率 $\varepsilon(\lambda)$ と放射計\# $\mathrm{i}$ の分光感度 $\tau_{\mathrm{i}}(\lambda)$ は, $0.1 \mu \mathrm{m}$ ごとの波長帯に対し求められてい る.

黒体型ヒータの数值実験結果例を，図 5 および図 6 上に線で示す．また，実験值と数值実験值間の誤差を，表 3 に示寸．誤差は放射エネルギ一量が小さい低温測定における近赤外域放射エネルギーの場合を除き $10 \%$ 程度で ある．これらは，放射計を用いた測定における周囲の反射の影響や電気的ノイズの他に，数值実験に利用したヒ 一タの分光放射率データのばらつき ${ }^{(9)}$ が原因と考えられる. 実験值と数值実験值は定性的に良好な結果を示し, 定量的にも 10\%程度の誤差にまとまっており，前節で提案した測定手法の妥当性を示している.

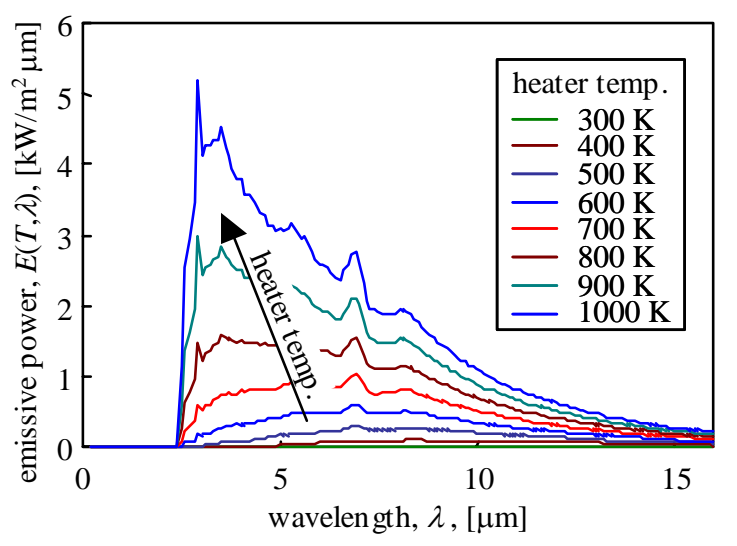

Fig. 7 Example of radiant energy from far IR type heater

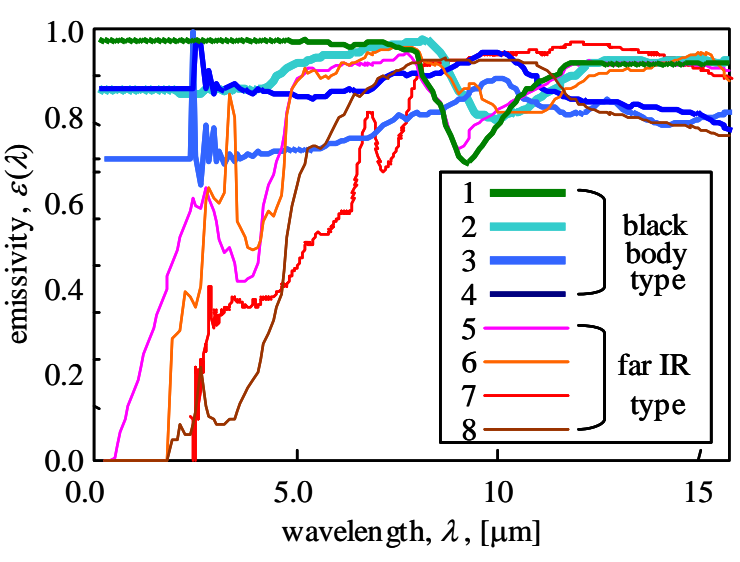

Fig. 8 Emissivity of 8 IR heaters obtained by FTIR

Table 4 Specification of 8 IR heaters

\begin{tabular}{|c|c|c|c|r|}
\hline No. & type & surface & size $\left[\mathrm{mm}^{2}\right]$ & max. load \\
\hline 1 & black body & plate & $50 \times 400$ & $1800[\mathrm{~W}]$ \\
\hline 2 & black body & spray & $200 \times 300$ & $800[\mathrm{~W}]$ \\
\hline 3 & black body & spray & $140 \times 380$ & $1200[\mathrm{~W}]$ \\
\hline 4 & black body & spray & $140 \times 380$ & $1200[\mathrm{~W}]$ \\
\hline 5 & far IR & plate & $100 \times 400$ & $700[\mathrm{~W}]$ \\
\hline 6 & far IR & plate & $100 \times 400$ & $670[\mathrm{~W}]$ \\
\hline 7 & far IR & spray & $275 \times 375$ & $1500[\mathrm{~W}]$ \\
\hline 8 & far IR & plate & $65 \times 235$ & $1000[\mathrm{~W}]$ \\
\hline
\end{tabular}

\section{5. 分光放射特性の定性的評価}

形状や分光放射特性の異なるヒータ 8 種類を対象に放射計を用いた実測実験を行った. 予め FTIR を用いて得 た分光放射特性を図 8 に, ヒータの仕様を表 4 に示す. 図 8 では, 太線が黒体型ヒータ, 細線が遠赤外型ヒータ の分光放射特性值を示している. 表 4 における第 3 列目はヒータ表面板の性状を表し，“spray” はセラミックス を金属板に溶射したもの，“plate” はセラミックスを板状に焼結成形したものを示す．いずれのヒータも，内部の 電熱線により表面板が加熱され，セラミックス表面が赤外域の放射エネルギーを発する仕組みである.

図 9(a) (c)に全域 $E_{1}(T)$, 近赤外域 $E_{2}(T)$, 遠赤外域 $E_{3}(T)$ の各測定波長帯域別の放射エネルギーとヒータの表面 温度の関係を, 図 10(a) ( c)に近赤外域 /全域 $\left[E_{2}(T) / E_{1}(T)\right]$, 遠赤外域 /全域 $\left[E_{3}(T) / E_{1}(T)\right]$, 近赤外域/遠赤外域 $\left[E_{2}(T) / E_{3}(T)\right]$ の放射エネルギーの比とヒータの表面温度の関係を示す.いずれも実測值である. 太点線は黒体を対 象とした数值実験值である. 


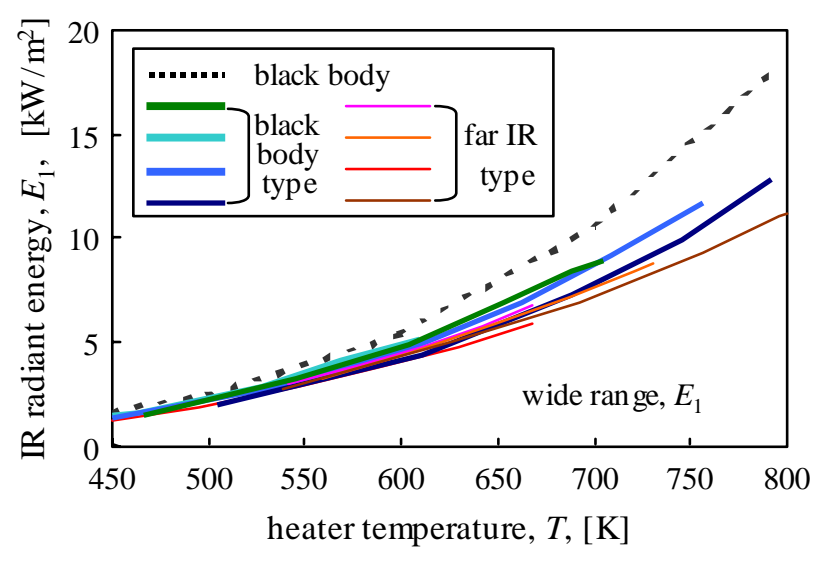

(a) wide range

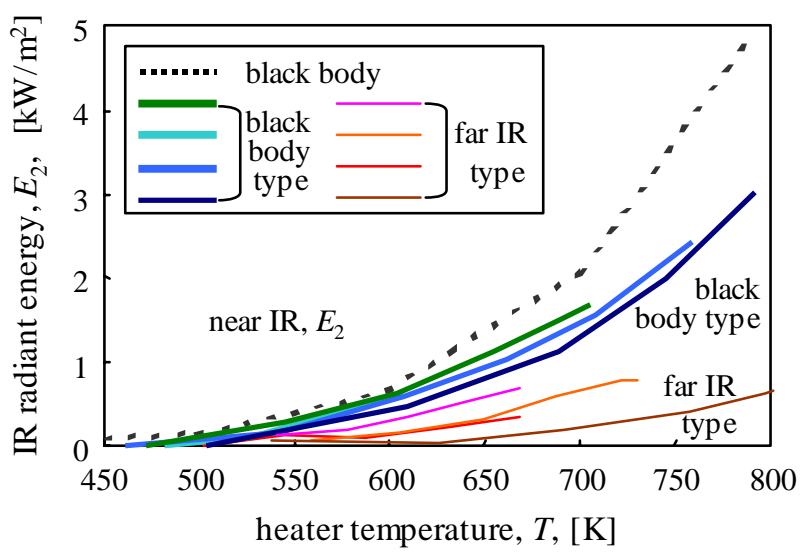

(b) near IR

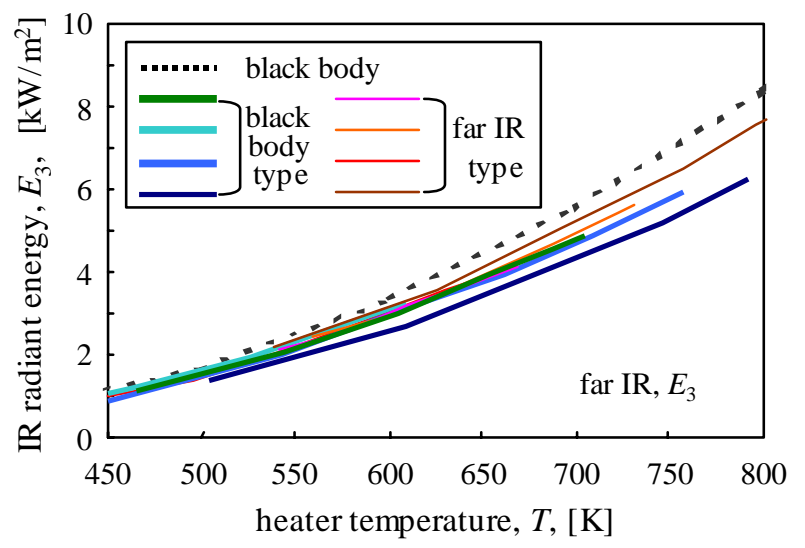

(c) far IR

Fig. 9 IR radiation energy vs. heater temperature

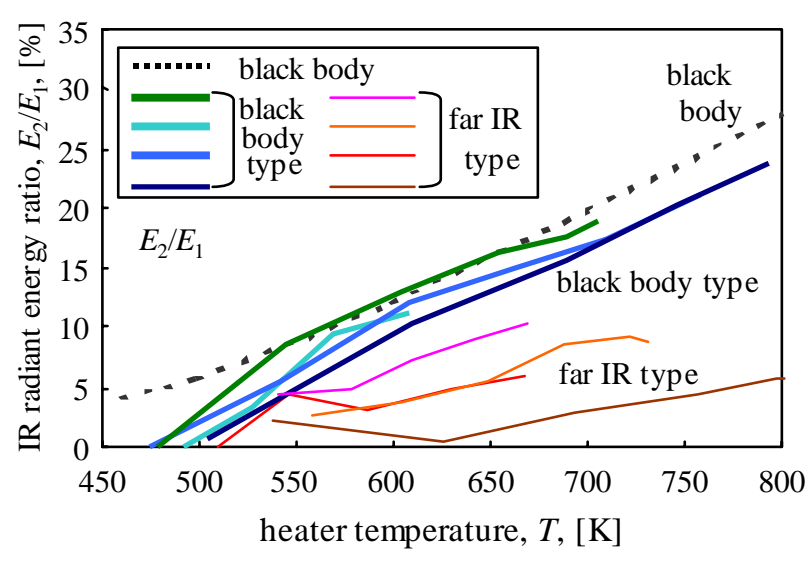

(a) near IR/wide range

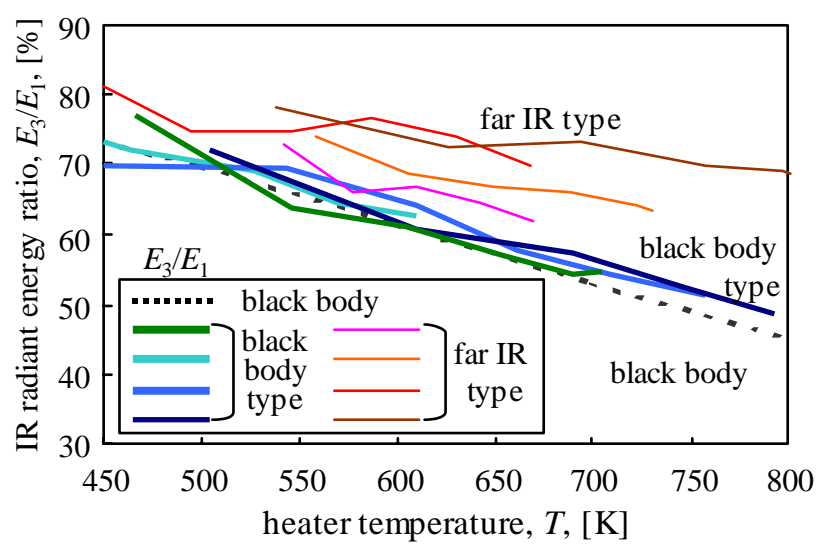

(b) far IR/wide range

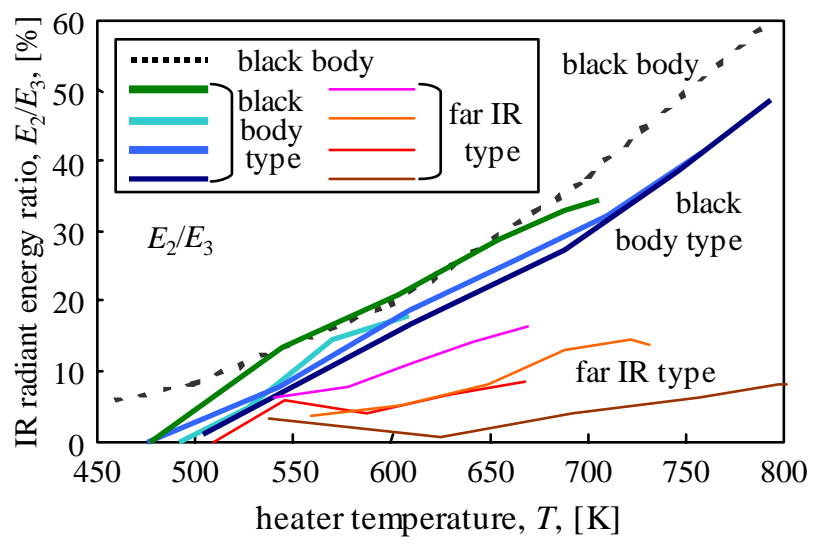

(c) near IR/far IR

Fig. 10 IR radiation energy ratio vs. heater temperature

放射エネルギーの最大位置は温度上昇に伴い短波長側にずれていくことから，ヒータを高温で使用することは 効率の悪い方法であるとの解釈が，主に欧米を中心になされている．しかし，図 9(a)および図 9(c)では，放射特 性の種別に関わらず，高温でも黒体に近い遠赤外域放射エネルギー量を維持している．この結果から，一般的に 遠赤外域での放射率が高い食材，建材，セラミックス（陶磁器）など産業界における多くの被加熱材料に対して は，遠赤外型ヒータも高温で十分使用可能であり，一方，近赤外域のみの放射率が高い材料の加熱には向いてい ないことが分かる．図 9(b)では，ヒータの種別による違いが明確に現れ，遠赤外型ヒータは近赤外域放射エネル ギー量が少ないことが示された. 図 10(b)では, 遠赤外型ヒータは高温時における遠赤外域放射エネルギー／全域 放射エネルギー比が，黒体や黒体型ヒータと比較して大きいことが分かる．これは，遠赤外型ヒータは近赤外域 
で放射していないため，供給電力に対する遠赤外域放射エネルギーの放射効率が黒体あるいは黒体型ヒータより 高いことを示している．近赤外域と遠赤外域の放射エネルギ一量の比を表す図 10(c)では，以下のことが言える. 1) 黒体型ヒータは，遠赤外型ヒータと比較して温度上昇に伴う放射エネルギ一比の上昇率が高い. 2) ヒータの 中でも, 遠赤外域における放射率が高く近赤外域の放射率が低いヒータは放射エネルギ一比がより低く出ている. 以上のことから，近赤外域と遠赤外域の放射エネルギ一量の比と温度の関係を表すグラフは，分光放射率と明確 な対応があり，測定対象のヒータが黒体型か遠赤外型か判別することに適していると言える.

\section{6. 分光放射率の概略值測定法の開発}

前節までに得られた実測データにより，遠赤外型ヒータが $750 \mathrm{~K}$ 程度の高温でも十分使用可能であることを示 し，また，測定対象のヒータが黒体型か遠赤外型か判別する簡易評価法を確立した。しかし本評価法は，定性的 な判断しか行なえず，定量的な測定はできない. 本章では，前章までに提案した計測システムを用いて得られた データを利用し，ヒータの分光放射率の概略值を定量的に評価する手法を提案する. 表 5 に概略值測定法の流れ を示す.

\section{$6 \cdot 1$ 分光放射率のモデル化（因子の定義）}

分光放射率を定量的に評価するために，まずは波長と分光放射率の関係を数值で表せるようモデル化する.

遠赤外型ヒータは，近赤外域でほとんど放射せず，遠赤外域でほぼ一定の高い放射率を有する．よってヒータ の分光放射率を波長ごとに 3 個に区分けし，0～$\lambda_{1} \mu \mathrm{m}$ を放射率 0 区間， $\lambda_{1} \sim \lambda_{2} \mu \mathrm{m}$ を放射率の線形上昇区間， $\lambda_{2}$ $\mu \mathrm{m}$ 以降を一定放射率 $\varepsilon_{2}$ 区間とモデル化する. 線形上昇区間の波長幅を $\Delta \lambda\left(=\lambda_{2}-\lambda_{1}\right)$ と定義すると，ヒータの分 光放射率を決定する因子は， $\lambda_{1}, \Delta \lambda, \varepsilon_{2}$ の 3 個となる. 図 11 に分光放射率のモデル概略図を示す. なお黒体型 のヒータは，近赤外域以下の波長でも高い放射率を有しており，本研究では近似的に， $\lambda_{1} \approx 0$ と $\Delta \lambda \approx 0$ として扱 う。これら 3 個の因子を用いることで，対象とする全てのヒータを表すことができる.

Table 5 Flow of proposed method

\begin{tabular}{|l|l|}
\hline \multicolumn{1}{|c|}{ Forward analysis } & \multicolumn{1}{c|}{ Inverse analysis } \\
\hline 1) extract parameters, $\lambda, \Delta \lambda, \varepsilon_{2}$ & 5) obtain attributes, $a_{\mathrm{i}}$ \\
2) determine attributes, $a_{\mathrm{i}}$ & 6) input $a_{\mathrm{i}}$ to $\mathrm{RS}_{\mathrm{i}}$ \\
3) get $a_{\mathrm{i}}$ from sims. or exps. & 7) identify parameters \\
4) map response surfaces $\left(\mathrm{RS}_{\mathrm{i}}\right)$ & $\lambda, \Delta \lambda, \varepsilon_{2}$ \\
\hline
\end{tabular}

Table 6 Range of IR heater parameters

\begin{tabular}{|c|c|}
\hline parameter of IR heater & range \\
\hline$\lambda_{1}$ & $0.0 \sim 4.5[\mu \mathrm{m}]$ \\
\hline$\Delta \lambda$ & $0.0 \sim 9.0[\mu \mathrm{m}]$ \\
\hline$\left(\lambda_{2}\right)$ & $0.0 \sim 9.0[\mu \mathrm{m}]$ \\
\hline$\varepsilon_{2}$ & $0.55 \sim 1.0$ \\
\hline
\end{tabular}

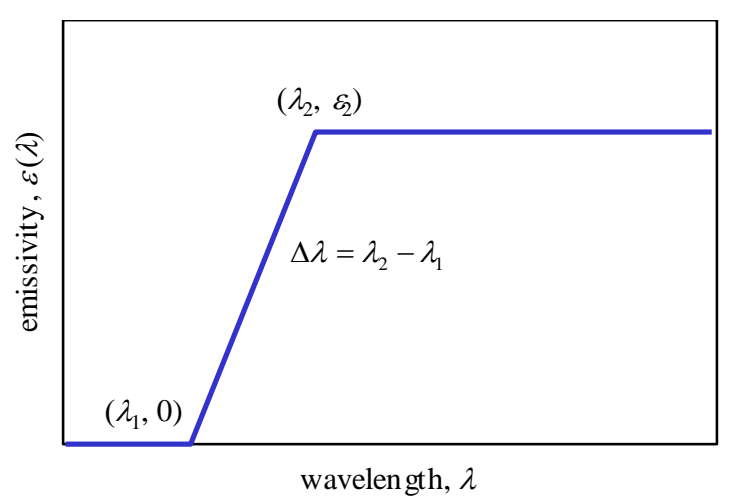

Fig. 11 Model of heat emissivity

\section{$6 \cdot 2$ 特性値の定義}

ヒータの分光放射率を表す 3 個の因子を決定するために, 実験で求められる特性值を定義する. 特性值はヒー タの分光放射特性を効果的に表さ襍ばならない. そこで, 以下 2 種類のデータから特性值を抽出することとした.
(A) 全域放射エネルギーと黒体放射エネルギーの比
$E_{1}(T) / E_{\mathrm{b} 1}(T)$
(B) 近赤外域放射エネルギーと遠赤外域放射エネルギーの比
$E_{2}(T) / E_{3}(T)$

(A)はヒータの測定波長帯域の平均的放射率を表し, (B)はヒータの種別を効果的に表す值である. なお, 黒体 放射エネルギー $E_{\mathrm{b} 1}(T)$ は式(1)から計算值として求められ, それ以外の $E_{1}(T), E_{2}(T), E_{3}(T)$ は実験で測定される. 2 種類のデータから簡易的かつ効果的にヒータの特性を抽出するため, 2 回の計測, 即ち 2 種類の温度 $T_{1}, T_{2}$ で実 
験を行う. 今回の研究では, ヒータの一般的な稼働範囲 ${ }^{(6)}$ 考慮し, 温度 $T_{1}, T_{2}$ は $500 \mathrm{~K}, 700 \mathrm{~K}$ とした. 3 種類 の放射計から 2 個ずつのデータが得られ，上述の(A), (B)のグラフ上にそれぞれ 2 点が決定する. 温度の異なる 2 点を結んだ直線の傾き $a_{1}, a_{2}$ と切片 $a_{3}, a_{4}$ を特性值とする. 特性值 $a_{1}, a_{2}, a_{3}, a_{4}$ は, 実験值から, それぞれ以 下の式で簡単に求めることができる.

$$
\begin{array}{r}
a_{1}=\frac{\frac{E_{1}\left(T_{2}\right)}{E_{\mathrm{b} 1}\left(T_{2}\right)}-\frac{E_{1}\left(T_{1}\right)}{E_{\mathrm{b} 1}\left(T_{1}\right)}}{T_{2}-T_{1}} \\
a_{2}=\frac{\frac{E_{2}\left(T_{2}\right)}{E_{3}\left(T_{2}\right)}-\frac{E_{2}\left(T_{1}\right)}{E_{3}\left(T_{1}\right)}}{T_{2}-T_{1}} \\
a_{3}=\frac{\frac{E_{1}\left(T_{1}\right)}{E_{b 1}\left(T_{1}\right)} T_{2}-\frac{E_{1}\left(T_{2}\right)}{E_{b 1}\left(T_{2}\right)} T_{1}}{T_{2}-T_{1}} \\
a_{4}=\frac{\frac{E_{2}\left(T_{1}\right)}{E_{3}\left(T_{1}\right)} T_{2}-\frac{E_{2}\left(T_{2}\right)}{E_{3}\left(T_{2}\right)} T_{1}}{T_{2}-T_{1}}
\end{array}
$$

\section{$6 \cdot 3$ 数値実験による順解析}

実験で求められた 4 個の特性值 $a_{1}, a_{2}, a_{3}, a_{4}$ から，ヒータの分光放射率を表す 3 個の因子 $\lambda_{1}, \Delta \lambda, \varepsilon_{2}$ を決定 するために, 応答曲面法を利用した逆解析を行う. まず順解析により, 未知因子と特性值の関係を応答曲面式と して導く. 順解析の手順を以下に示寸.

（1）工業界で使用されているヒータの種類を網羅する表 6 の範囲で 3 個の因子 $\left(\lambda_{1}, \Delta \lambda, \varepsilon_{2}\right)$ に対し水淮数 4 合計 64 種類の分光放射率を仮定する.

(2) 64 種類のヒータに対して，MS-エクセルを用いて式(5)に基づいた数值実験を行い，それぞれ 4 個の特性 值 $a_{\mathrm{i}}\left(a_{1}, a_{2}, a_{3}, a_{4}\right)$ を取得する.

（3）各特性值 $a_{\mathrm{i}}$ を 3 個の因子 $\left(\lambda_{1}, \Delta \lambda, \varepsilon_{2}\right)$ の 4 次関数（応答曲面式(10)）として表す. 各係数 $C_{\mathrm{j}}$ は，技術 計算ソフト Mathcad の最小二乗アルゴリズムを利用し決定した．因子が 3 個あるため，応答曲面式 $F$ は 4 次元空間で表現される. 4 個の応答曲面に関する係数 $C_{\mathrm{j}}$ および指数 $I_{\mathrm{j}}$ については付録に示した.

$$
a_{\mathrm{i}}=F_{\mathrm{i}}\left(\lambda_{1}, \Delta \lambda, \varepsilon_{2}\right)=\sum_{\mathrm{j}=0}^{34}\left[C_{\mathrm{j}} \times\left(\lambda_{1}\right)^{I_{\mathrm{j}, 0}} \times(\Delta \lambda)^{I_{\mathrm{j}, 1}} \times \varepsilon_{2}^{I_{\mathrm{j}, 2}}\right]
$$

\section{$6 \cdot 4$ 逆解析による未知因子の決定}

逆解析の目的は, 順解析で求めた 4 個の応答曲面式(10)を用いて, 分光放射率を決定することである. 決定す べき未知因子は， $\lambda_{1}, \Delta \lambda, \varepsilon_{2}$ の 3 個である. 逆解析の手順を以下に示寸.

(1) 分光放射率が未知である対象ヒータに対し，表面温度 $500 \mathrm{~K}, 700 \mathrm{~K}$ で実験を行い，式(6) (9)を用いて 4 個の特性值 $a_{\mathrm{i} \text {-exp }}$ を決定する.

（2）実験で得た特性值 $a_{\mathrm{i}-\mathrm{exp}}$ と，任意の因子 $\left(\lambda_{1}, \Delta \lambda, \varepsilon_{2}\right)$ を応答曲面式 $F_{\mathrm{i}}$ に代入して得られる特性值 $a_{\mathrm{i}-\mathrm{rs}}$ との差の二乗和 $D$ が最小になるように，因子を選択する.

$$
D=\sum_{\mathrm{i}=0}^{4}\left[a_{\mathrm{i}-\exp }-a_{\mathrm{i}-\mathrm{rs}}\left(\lambda_{1}, \Delta \lambda, \varepsilon_{2}\right)\right]^{2}
$$

選択された因子が，対象ヒータの分光放射特性を表す未知因子に相当する.

（3）未知因子を基に分光放射率と波長の関係（図 11）を作成する. 


\section{7. 分光放射率測定結果}

6 章で構築した分光放射率簡易測定法の信頼性を確認する. 6.1 節のモデル化に従ったヒータと実在ヒータに対 する結果を示す。

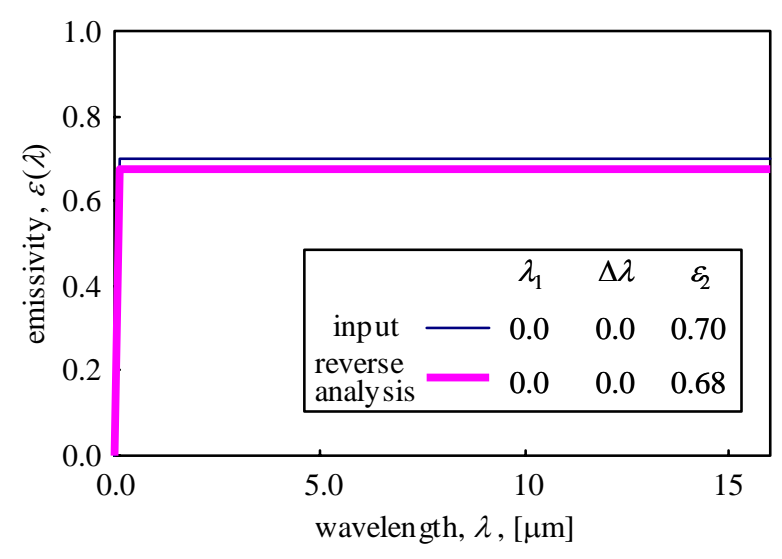

(a) black body type

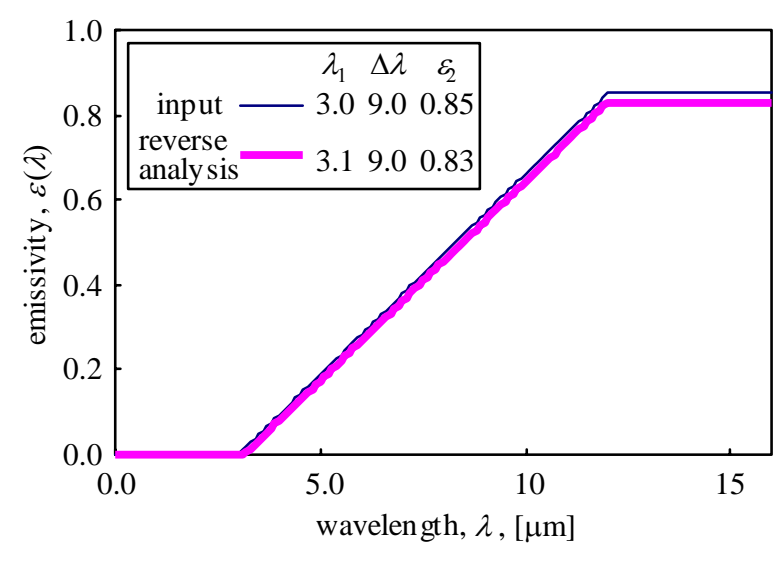

(b) far IR type

Fig. 12 Inversed results of numerical model
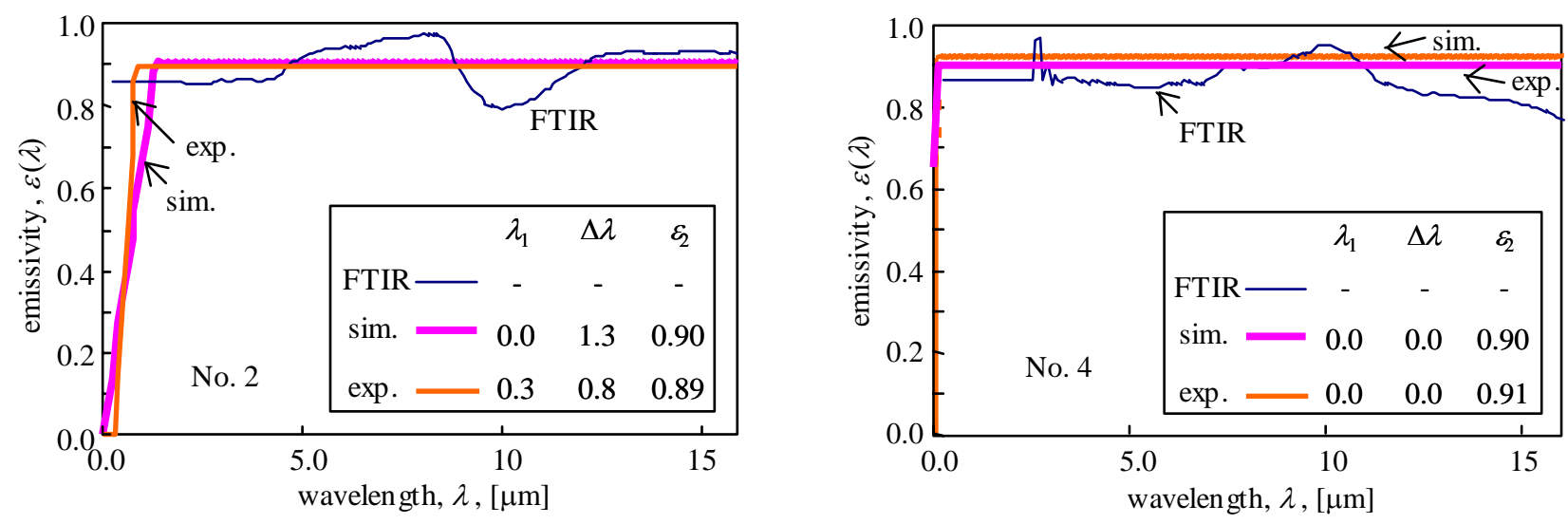

(a) black body types
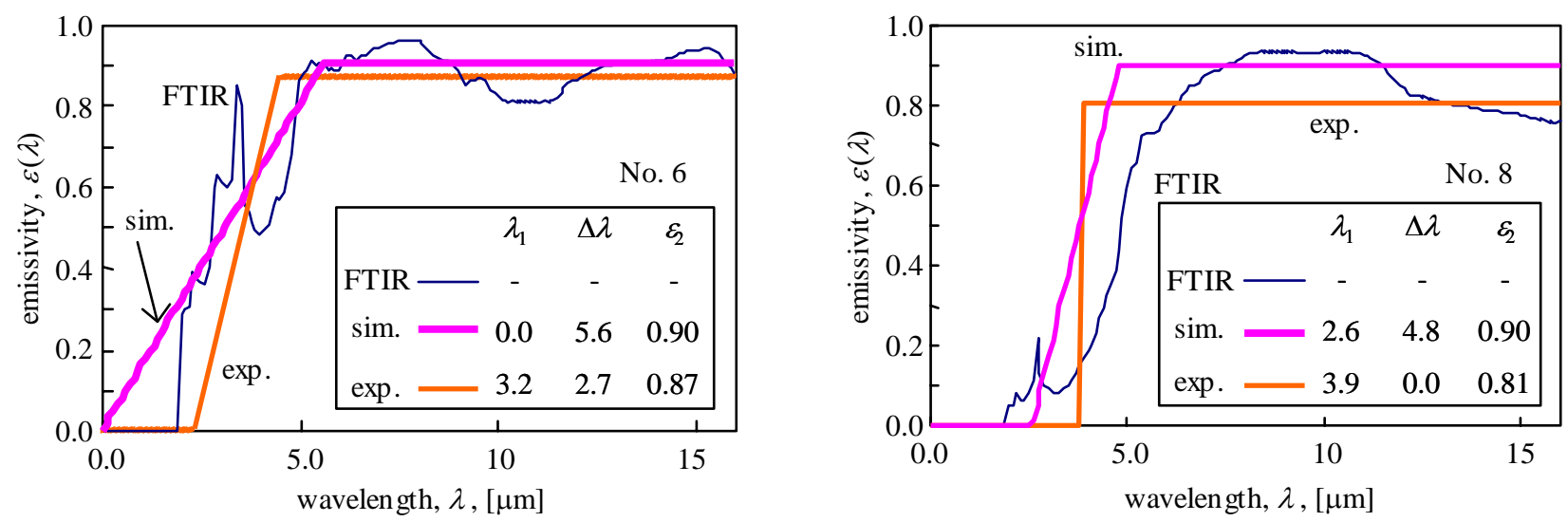

(b) far IR types

Fig. 13 Inversed results of real heater 


\section{$7 \cdot 1$ モデル化ヒータに対する結果}

6.1 節のモデル化に従ったヒータ $\left(\lambda_{1}, \Delta \lambda, \varepsilon_{2}\right)$ に対して, 数值実験を行い, それらデータを用いて逆解析し た結果例を，図 12 に示す. (a)は黒体型ヒータの例，(b)は遠赤外型ヒータの例である. 細線が入力データを, 太 線が逆解析によって求められた結果を示す．ヒータの種類に依存することなく，分光放射特性を同定できること が示された。

\section{$7 \cdot 2$ 実在ヒータに対する結果}

工業界で利用されている実在ヒータの分光放射率は, 図 8 に示したように局所的に高い值を持つなど, 6.1 節の モデル化ヒータとは詳細が異なる. 本節では, 実在ヒータを対象として, 分光放射率簡易測定を行なった. まず, 式(5)に基づいた数值実験から特性值を求め, 6.4 節の手順に従い分光放射率と波長の関係を定めた. 続いて 4 章 で定めた手法に基づいた実測実験から特性值を求め, 6.4 節の手順に従い分光放射率と波長の関係を定めた.

図 13(a)に 2 種類の黒体型ヒータ（表 4 中の No. 2 と No. 4）の結果を, 図 13(b)に 2 種類の遠赤外型ヒータ（表 4 中の No. 6 と No. 8) の結果を示寸. 細実線が FTIR によって求めた分光放射率を, 太実線が数值実験の結果を, 中実線が実験の結果を示寸，放射率線形上昇区間において数值実験結果と実測実験結果に若干の違いが見られる ものの，遠赤外域の放射率では $10 \%$ 程度の誤差にとどまり，分光放射率の大域的な值を得ることには成功してい る. FTIR 法では, ヒータ素材の分光放射率の局所的な詳細值を得ることが出来るが，ヒータ形状や加熱状況など を維持した稼動環境での測定は難しい. 放射加熱効率を評価する際には, 被加熱物の分光放射特性と, 加熱体 (七 一タ）の稼働環境における大域的な分光放射特性が重要となる. 本手法を用いれば，実在ヒータの大域的分光放 射率を求められる.

\section{8. 結言}

遠赤外線ヒータの分光放射特性を簡易的に評価する手法を確立した．得られた知見を以下に示す.

・複数のバンドパスフィルターを装着した市販の放射計を用いて，波長帯域別の放射エネルギーを簡易的に求 める手法を確立した.

・遠赤外型ヒータは，高温使用時でも黒体と同程度の遠赤外域放射エネルギーを放射していることを，実測デ 一タで確認した. 入力電力に対する遠赤外線放射効率は, 黒体型ヒータより遠赤外型ヒータの方が高い.

・近赤外域放射エネルギーと遠赤外域放射エネルギーとの比と温度の関係から, 遠赤外線ヒータの種別を判別 できる.

・表計算ソフトを利用し簡単に数值実験を行える手法を確立し, 実際の実験の妥当性を確認した. フィルター を変更するなど近赤外域と遠赤外域の境界等を変更した場合のデータベース構築も, 本数值実験手法を用い れば簡単に行える.

・応答曲面法を利用した逆解析手法で，稼働環境における実在遠赤外線ヒータの大域的分光放射率が求められ ることを示した.

本研究は、社団法人遠赤外線協会 遠赤外域放射エネルギー簡易評価委員会で行ったものである.

\section{文献}

（1）岡本芳三，遠赤外線リモートセンシング熱計測法(1994)，コロナ社.

（2）清水賢，ほか 16名, “JIS R 1801:2002 遠赤外ヒータに放射部材として用いられるセラミックスの FTIR による分光 放射率測定方法”, 日本規格協会, (2002)

(3) Weisman, D. W., “Infrared Drying and Curing Systems”, Metal Finishing, Vol. 96, No. 5A (1997), p.378.

（4）菊地眞, ほか 17 名, “JIS Z 8117:2002 遠赤外線用語”, 日本規格協会, (2002).

（5）寺田博之, 阪上隆英監修, 赤外線サーモグラフィによる設備診断・非破壊評価ハンドブック(2004), 日本非破壊検 查協会. 
（6）木村嘉孝，ほか 15 名, “遠赤外ヒータの遠赤外域放射エネルギー分布測定方法の標準化に関する調查研究成果報告 書”, 遠赤外線協会, (2002).

（7）木村嘉孝，ほか 18 名, “遠赤外ヒータの遠赤外域放射エネルギー分布測定方法の標準化に関する調查研究成果報告 書”, 遠赤外線協会, (2003).

（8）木村嘉孝，ほか 15 名，“遠赤外ヒー夕の放射エネルギーを簡易的に評価する方法の調查研究報告書”，遠赤外線協 会, (2006).

（9）小笠原永久, “遠赤外ヒータの放射エネルギーを簡易的に評価する方法の調查研究報告”, 遠赤外線協会, (2007).

付

式(10)で表される応答曲面の係数 $C_{\mathrm{j}}$ および指数 $I_{\mathrm{j}}$ を付表 $\mathrm{A} 1$ および $\mathrm{A} 2$ に示す.

Table A1 Coefficients of response surfaces, $C_{\mathrm{j}}$

\begin{tabular}{|c|c|c|c|c|}
\hline$C_{\mathrm{j}}$ & $a_{1}$ & $a_{2}$ & $a_{3}$ & $a_{4}$ \\
\hline$C_{0}$ & 2.129E-02 & $-8.764 \mathrm{E}+00$ & $-3.096 \mathrm{E}-02$ & $1.445 \mathrm{E}+01$ \\
\hline$C_{1}$ & $1.064 \mathrm{E}-02$ & $-4.382 \mathrm{E}+00$ & $-1.548 \mathrm{E}-02$ & $7.224 \mathrm{E}+00$ \\
\hline$C_{2}$ & $1.144 \mathrm{E}+00$ & $-1.192 \mathrm{E}+03$ & $1.833 \mathrm{E}+00$ & $-8.261 \mathrm{E}+02$ \\
\hline$C_{3}$ & $-3.616 \mathrm{E}+00$ & $3.725 \mathrm{E}+03$ & $-5.583 E+00$ & $2.514 \mathrm{E}+03$ \\
\hline$C_{4}$ & $1.916 \mathrm{E}-03$ & \begin{tabular}{|l|}
$-7.888 E-01$ \\
\end{tabular} & $-2.787 \mathrm{E}-03$ & $1.300 \mathrm{E}+00$ \\
\hline$C_{5}$ & $6.653 \mathrm{E}-04$ & $-2.739 \mathrm{E}-01$ & $-9.676 \mathrm{E}-04$ & 4.515E-01 \\
\hline$C_{6}$ & $-3.265 \mathrm{E}-02$ & $1.344 \mathrm{E}+01$ & 4.749E-02 & $-2.216 \mathrm{E}+01$ \\
\hline$C_{7}$ & $4.235 \mathrm{E}+00$ & $-4.303 E+03$ & $6.247 \mathrm{E}+00$ & $-2.811 E+03$ \\
\hline$C_{8}$ & $-6.531 \mathrm{E}-02$ & $2.688 \mathrm{E}+01$ & $9.498 \mathrm{E}-02$ & $-4.432 \mathrm{E}+01$ \\
\hline$\overline{C_{9}}$ & $2.661 \mathrm{E}-03$ & $-1.095 \mathrm{E}+00$ & $-3.871 \mathrm{E}-03$ & $1.806 \mathrm{E}+00$ \\
\hline$C_{10}$ & $3.612 \mathrm{E}-04$ & $-1.745 \mathrm{E}-02$ & \begin{tabular}{|l|}
$-1.393 E-04$ \\
\end{tabular} & $6.502 \mathrm{E}-02$ \\
\hline$C_{11}$ & $6.286 \mathrm{E}-05$ & $3.432 \mathrm{E}-03$ & $-3.871 \mathrm{E}-05$ & $1.806 \mathrm{E}-02$ \\
\hline$C_{12}$ & $-1.572 \mathrm{E}-03$ & \begin{tabular}{|l|}
$-2.961 E-01$ \\
\end{tabular} & $2.162 \mathrm{E}-03$ & $-1.009 \mathrm{E}+00$ \\
\hline$C_{13}$ & $2.311 \mathrm{E}-02$ & $-5.233 \mathrm{E}+00$ & $-4.802 \mathrm{E}-02$ & $2.241 \mathrm{E}+01$ \\
\hline$C_{14}$ & $-8.316 \mathrm{E}-03$ & 9.403E-01 & $6.326 \mathrm{E}-03$ & $-2.952 \mathrm{E}+00$ \\
\hline$C_{15}$ & $1.150 \mathrm{E}-03$ & $-4.074 \mathrm{E}-01$ & \begin{tabular}{|l|}
$-2.787 E-04$ \\
\end{tabular} & $1.300 \mathrm{E}-01$ \\
\hline$C_{16}$ & $-2.169 \mathrm{E}+00$ & $2.271 \mathrm{E}+03$ & $-3.039 \mathrm{E}+00$ & $1.366 \mathrm{E}+03$ \\
\hline$C_{17}$ & 7.044E-02 & $-2.504 \mathrm{E}+01$ & -9.603E-02 & $4.481 \mathrm{E}+01$ \\
\hline$C_{18}$ & $-1.609 \mathrm{E}-02$ & $6.136 \mathrm{E}+00$ & $8.647 \mathrm{E}-03$ & $-4.035 \mathrm{E}+00$ \\
\hline$C_{19}$ & 1.109E-03 & $-5.823 \mathrm{E}-01$ & $-3.096 \mathrm{E}-04$ & $1.445 \mathrm{E}-01$ \\
\hline$C_{20}$ & $-1.085 \mathrm{E}-04$ & $5.656 \mathrm{E}-02$ & $-1.356 \mathrm{E}-04$ & 5.859E-02 \\
\hline$C_{21}$ & $5.879 \mathrm{E}-05$ & $-3.625 \mathrm{E}-02$ & $9.350 \mathrm{E}-05$ & $-4.111 \mathrm{E}-02$ \\
\hline$C_{22}$ & $-8.315 \mathrm{E}-04$ & 5.324E-01 & $-1.343 \mathrm{E}-03$ & 5.929E-01 \\
\hline$C_{23}$ & $2.694 \mathrm{E}-03$ & $-1.846 \mathrm{E}+00$ & 4.013E-03 & $-1.809 \mathrm{E}+00$ \\
\hline$C_{24}$ & $2.420 \mathrm{E}-03$ & $-1.345 \mathrm{E}+00$ & $3.881 \mathrm{E}-03$ & $-1.677 \mathrm{E}+00$ \\
\hline$C_{25}$ & $-2.262 \mathrm{E}-04$ & $1.350 \mathrm{E}-01$ & $-4.374 \mathrm{E}-04$ & 1.902E-01 \\
\hline$C_{26}$ & $-5.033 \mathrm{E}-03$ & $1.994 \mathrm{E}+00$ & $3.064 \mathrm{E}-03$ & $-1.331 \mathrm{E}+00$ \\
\hline$C_{27}$ & $-1.213 \mathrm{E}-02$ & $7.700 \mathrm{E}+00$ & $-3.011 \mathrm{E}-02$ & $1.330 \mathrm{E}+01$ \\
\hline$C_{28}$ & $2.154 \mathrm{E}-03$ & $-1.586 \mathrm{E}+00$ & $6.320 \mathrm{E}-03$ & $-2.927 \mathrm{E}+00$ \\
\hline$C_{29}$ & $-3.602 E-05$ & \begin{tabular}{|c|}
$6.254 \mathrm{E}-02$ \\
\end{tabular} & $-1.867 \mathrm{E}-04$ & $1.085 \mathrm{E}-01$ \\
\hline$C_{30}$ & 4.074E-01 & $-4.025 E+02$ & 6.899E-01 & $-3.091 \mathrm{E}+02$ \\
\hline$C_{31}$ & $-1.999 \mathrm{E}-02$ & $8.233 \mathrm{E}+00$ & $3.996 \mathrm{E}-02$ & $-1.909 \mathrm{E}+01$ \\
\hline$C_{32}$ & $1.283 \mathrm{E}-02$ & \begin{tabular}{|l|}
$-8.429 E+00$ \\
\end{tabular} & \begin{tabular}{|c|}
$-4.828 \mathrm{E}-03$ \\
\end{tabular} & $3.043 \mathrm{E}+00$ \\
\hline$C_{33}$ & $-4.796 \mathrm{E}-03$ & $3.568 \mathrm{E}+00$ & -6.478E-03 & $2.752 \mathrm{E}+00$ \\
\hline$C_{34}$ & 5.355E-04 & \begin{tabular}{|c|}
$-4.214 \mathrm{E}-01$ \\
\end{tabular} & $1.068 \mathrm{E}-03$ & $-4.801 \mathrm{E}-01$ \\
\hline
\end{tabular}

Table A2 Exponents of response surfaces, $I_{\mathrm{j}}$

\begin{tabular}{|r|r|r|r|}
\hline$I_{\mathrm{j}}$ & $I_{\mathrm{j}, 0}$ & $I_{\mathrm{j}, 1}$ & $I_{\mathrm{j}, 2}$ \\
\hline$I_{0}$ & 1 & 0 & 3 \\
\hline$I_{1}$ & 0 & 1 & 3 \\
\hline$I_{2}$ & 0 & 0 & 4 \\
\hline$I_{3}$ & 0 & 0 & 3 \\
\hline$I_{4}$ & 1 & 1 & 2 \\
\hline$I_{5}$ & 0 & 2 & 2 \\
\hline$I_{6}$ & 0 & 1 & 2 \\
\hline$I_{7}$ & 0 & 0 & 2 \\
\hline$I_{8}$ & 1 & 0 & 2 \\
\hline$I_{9}$ & 2 & 0 & 2 \\
\hline$I_{10}$ & 1 & 2 & 1 \\
\hline$I_{11}$ & 0 & 3 & 1 \\
\hline$I_{12}$ & 0 & 2 & 1 \\
\hline$I_{13}$ & 0 & 1 & 1 \\
\hline$I_{14}$ & 1 & 1 & 1 \\
\hline$I_{15}$ & 2 & 1 & 1 \\
\hline$I_{16}$ & 0 & 0 & 1 \\
\hline$I_{17}$ & 1 & 0 & 1 \\
\hline$I_{18}$ & 2 & 0 & 1 \\
\hline$I_{19}$ & 3 & 0 & 1 \\
\hline$I_{20}$ & 1 & 3 & 0 \\
\hline$I_{21}$ & 0 & 4 & 0 \\
\hline$I_{22}$ & 0 & 3 & 0 \\
\hline$I_{23}$ & 0 & 2 & 0 \\
\hline$I_{24}$ & 1 & 2 & 0 \\
\hline$I_{25}$ & 2 & 2 & 0 \\
\hline$I_{26}$ & 0 & 1 & 0 \\
\hline$I_{27}$ & 1 & 1 & 0 \\
\hline$I_{28}$ & 2 & 1 & 0 \\
\hline$I_{29}$ & 3 & 1 & 0 \\
\hline$I_{30}$ & 0 & 0 & 0 \\
\hline$I_{31}$ & 1 & 0 & 0 \\
\hline$I_{32}$ & 2 & 0 & 0 \\
\hline$I_{33}$ & 3 & 0 & 0 \\
\hline$I_{34}$ & 4 & 0 & 0 \\
\hline & & & \\
\hline
\end{tabular}

